\title{
EFFECT OF PRECEDING CROPS AND FOLIAR MICRONUTRIENTS APPLICATIONS ON YIELD AND YIELD COMPONENTS OF BREAD WHEAT UNDER SANDY SOIL CONDITIONS
}

\author{
Ahmed M. Abd Allah', A.M. Morsy ${ }^{1 *}$, Manal S. Abd El-Haliem² and M.S. Mohamed ${ }^{3}$ \\ 1. Filed Crop Res. Inst., Agric. Res. Cent., Ismailia, Egypt \\ 2. Agron. Dept., Fac. Agric., Suez Canal Univ., Egypt \\ 3. Soils, Water and Environ. Res. Inst., Agric. Res. Cent., Giza, Egypt
}

Received: 06/02/2020; Accepted: 09/03/2020

\begin{abstract}
Two field experiments were conducted during 2016/2017 and 2017/2018 seasons at the experimental farm of the Agricultural Research Station, Agric. Res. Center, Ismailia Governorate, Egypt (Lat. $30^{\circ} 35^{\prime} 30^{\prime \prime} \mathrm{N}$, Long. $32^{\circ} 14^{\prime} 50^{\prime \prime} \mathrm{E}, 10 \mathrm{~m} \mathrm{ASL}$ ), to evaluate the effect of fallow (control), clover and fodder maize as a preceding crops and foliar application of some micronutrients on yield and yield components of wheat cv. Gemmiza 11. The experimental design was split plot with three replications. Main plots were allocated by preceding crops and sub plots were occupied by three micronutrients salts $\mathrm{FeSO}_{4}, \mathrm{ZnSO}_{4}$ and $\mathrm{MnSO}_{4}$, in seven combinations of micronutrients foliar application T1: $(\mathrm{Fe}+\mathrm{Zn}+\mathrm{Mn}), \mathrm{T} 2:(\mathrm{Fe}+\mathrm{Zn}), \mathrm{T} 3:(\mathrm{Fe}+\mathrm{Mn}), \mathrm{T} 4: \mathrm{Fe}, \mathrm{T} 5:(\mathrm{Zn}+\mathrm{Mn}), \mathrm{T} 6: \mathrm{Zn}$ and T7: Mn. Micronutrients were sprayed three times at 30,60 and 90 days after sowing. Results showed that wheat significantly affected by the preceding summer crops. Clover as a preceding crop left good residual effect on wheat plant which gave the highest values for all studied characters e.g. plant height, number of spikes $/ \mathrm{m}^{2}$, No. of spikelets/spike, No. of grains/spike, 1000 grain weight and grain yield as well as straw and grain contents from $\mathrm{Fe}, \mathrm{Mn}$ and $\mathrm{Zn}$ in the two seasons. With respect to micronutrients, the results showed that the differences between these treatments had significant effect on each of plant height, number of spikes $/ \mathrm{m}^{2}$, No. of spikelets/spike, No. of grains/spike, 1000 grain weight and grain yield. The foliar application of mixture nutrients $(\mathrm{Fe}+\mathrm{Mn}+\mathrm{Zn})$ produced the highest values of yield and its components during both seasons. Moreover, the foliar spray of $\mathrm{Fe}, \mathrm{Mn}$ and $\mathrm{Zn}$ (alone or together and all three nutrients) has significant effect on wheat straw and grain-Fe, $\mathrm{Mn}$ and $\mathrm{Zn}$ concentration during the two seasons. Also, the results indicated that the interaction between preceding crops and micronutrients treatments had insignificant effect on all studied characters, except 1000 grain weight in the first season and number of spikelets/spike in the second one. In conclusion growing wheat following to clover and foliar application by mixture of $\mathrm{Fe}+\mathrm{Mn}+\mathrm{Zn}$ produced the maximum net income valued 2186 and 2098 LE.fad $^{-1}$ during two seasons, respectively, compared to the other treatments.
\end{abstract}

Key words: Wheat, preceding crop, mironutrients.

\section{INTRODUCTION}

Wheat (Triticum aestivum, L.) is one of the most important cereal crops in terms of area and production. Also, wheat is considered as the first leading cereal crop in the world, due to its position as a staple food for the majority of the world population. In Egypt, wheat is the most important food crop and provides almost $35 \%$ of the total food calories of the Egyptian people. Increasing wheat productivity in sandy soils is one of the main targets due to its short supply which mandated importing about $50 \%$ of the needed wheat, taking into account the climate

\footnotetext{
*Corresponding author: Tel. : +201015757521

E-mail address: amgad.moursy@gmail.com
} 
change, the gap is expected to increase in the future (Ouda et al., 2017).

Sandy soils are known to be poor in macro and micronutrients especially available nitrogen due to their low content of organic matter. Therefore, appropriate wheat positioning in cropping sequence under efficient management practices may facilitate better utilization of growth resources to enhance growth features. Several investigators showed that leguminous crops are the best precursors for all soil and productivity of wheat. The net benefits of legumes are often equivalent to the addition of 50-100 kg N per ha as fertilizer (Phoomthaisong et al., 2003), especially $\mathrm{N}$ deficiency is one of the major yield limiting factors for cereals (Shah et al., 2003). Inclusion of legumes increases soil fertility and consequently the productivity of succeeding cereal crops (Ghosh et al., 2007). Less $\mathrm{N}$ uptake by legumes plants increased the $\mathrm{N}$ uptake by the following nonlegume enhancing photosynthesis to increase photo assimilates translocation to plant different sinks and, in turn, enhancing yield and yield attributes (Khalil et al., 2011). Also, Kumar and Sharma (2000) reported that growing of a legume crop in the previous season affect the growth and development of wheat. Growing wheat after peas or fahl-berseem and/or soybean increaseing, plant height, number of spikes $/ \mathrm{m}^{2}$, spike length, weight of grains/spike and 1000grain weight as well as grain yield fad. ${ }^{-1}$ compared with wheat grown after fodder maize or maize (Abou-Kerisha, 1998; Seif El-Nasr and Zahran, 1998; Badr, 1999). Wheat cultivated after legumes has significantly higher grain and straw yields and net income than after cereal crop (Abou-Kerisha et al., 2008; Gangaiah et al., 2012). Maadi et al. (2012) found that species of preceding crops significantly affect wheat yield and its attributes and grain legumes such as mung bean might help to maximize wheat yield in a crop rotation system. Fahl berseem as preceding crops for wheat gave significantly higher grain yield compared with fodder maize. Similarly, the highest grain yield and net income after fahl berseem, $(2.959,2.980$ ton and $5422,5414 \mathrm{LE})$ in the $1^{\text {st }}$ and $2^{\text {nd }}$ seasons, respectively (El-Mehy et al., 2014).

It is perceived that micronutrients play a pivotal role in the yield improvement (Rehm and Sims, 2006). These micronutrients help in chlorophyll formation, nucleic acid, protein synthesis and play an active role in several enzymatic activities of photosynthesis as well as respiration (Reddy, 2004). Chaudry et al. (2007) stated that micronutrients ( $\mathrm{Zn}, \mathrm{Fe}, \mathrm{B})$ significantly increased the wheat yield over control when applied singley or in combination with each other. Zain et al. (2015) found that foliar application of micronutrients substantially improved each of plant height, spike length, No. of spikelets/spike, No. of grains/spike, grain and biological as well as harvest index of wheat. Among treatments, foliar application of $\mathrm{FeSO}_{4}+\mathrm{ZnSO}_{4}+\mathrm{MnSO}_{4}$ remained comparatively better regarding yield related attributes of wheat. Also, Aziz et al. (2019) showed the effectiveness of foliar feeding for growth and yield parameters, compared to the control without foliar feeding, foliar application of wheat crop increased tillering ability, spike length and grain yield. Therefore, foliar feeding of micronutrients could be an effective approach to enrich wheat grains with essential nutrients for correcting malnutrition. The foliar application of $\mathrm{Fe}+\mathrm{Zn}+\mathrm{Mn}$ treatments had significantly increased crop in two growing seasons. However the interaction of varieties and $\mathrm{Fe}+\mathrm{Zn}+\mathrm{Mn}$ foliar application showed a significant impact on some traits compared to the control. The highest values of all these studied traits were obtained by applying $\mathrm{Fe}+\mathrm{Zn}+\mathrm{Mn}$ as a foliar spray Abdel-Motagally et al. (2016).

The aim of this study was to evaluate the effect of fallow (control), clover and fodder maize as preceding crops as well as the effect of some micronutrients on yield and yield components of wheat cv. Gemmiza 11.

\section{MATERIALS AND METHODS}

\section{Site Description}

Two field experiments were carried out at Ismailia Agricultural Experiments and Research Station, ARC, Ismailia Governorate (Lat. $30^{\circ}$ $35^{\prime} 30^{\prime \prime} \mathrm{N}$, Long. $32^{\circ} 14^{\prime} 50^{\prime \prime} \mathrm{E}, 10 \mathrm{~m}$ ASL), under sprinkler irrigation system during 2016/ 2017 and 2017/2018 seasons. The experimental soil was sandy in texture. Physical properties and chemical analysis of the experimental soil sites $(0-30 \mathrm{~cm}$ depth) are stated in Table 1 according to standard methods described by Piper (1950) and Jackson (1973). DTPAextractable $\mathrm{Fe}, \mathrm{Mn}$ and $\mathrm{Zn}$ were measured in soil 
Table 1. Some physical and chemical properties of the experimental soil in the two seasons of investigation (2016/2017 and 2017/2018)

\begin{tabular}{|c|c|c|c|c|c|}
\hline Property & $\begin{array}{c}\text { First season } \\
2016 / 2017\end{array}$ & $\begin{array}{c}\text { Second season } \\
2017 / 2018\end{array}$ & Property & $\begin{array}{c}\text { First season } \\
\text { 2016/2017 }\end{array}$ & $\begin{array}{c}\text { Second season } \\
2017 / 2018\end{array}$ \\
\hline Physical analysis & \multicolumn{5}{|c|}{ Chemical properties } \\
\hline Coarse sand (\%) & 74.60 & 72.50 & $\mathrm{pH}$ & 7.86 & 7.90 \\
\hline Fine sand $(\%)$ & 19.50 & 19.65 & $\mathrm{EC} \mathrm{dsm}{ }^{-1}$ & 0.95 & 1.04 \\
\hline Silt $(\%)$ & 2.45 & 3.50 & OM \% & 0.42 & 0.53 \\
\hline Clay $(\%)$ & 3.45 & 4.35 & $\mathrm{Ca} \mathrm{CO}_{3} \%$ & 1.95 & 2.13 \\
\hline \multirow[t]{2}{*}{ Texture } & Sandy & Sandy & & & \\
\hline & \multicolumn{5}{|c|}{ Chemical properties } \\
\hline \multicolumn{2}{|c|}{ Soluble cations $\left(\right.$ mmolic $\mathrm{l}^{-1}$ ) } & \multicolumn{4}{|c|}{ Soluble anions (mmolic $\left.\mathrm{I}^{-1}\right)$} \\
\hline $\mathrm{Ca}^{2+}$ & 4.30 & 4.39 & $\mathrm{CO}_{3}{ }^{2-}$ & - & - \\
\hline $\mathrm{Mg}^{2+}$ & 1.82 & 1.90 & $\mathrm{HCO}_{3}^{-}$ & 2.15 & 2.28 \\
\hline $\mathrm{Na}^{+}$ & 2.43 & 2.51 & $\mathrm{Cl}-$ & 2.65 & 2.75 \\
\hline $\mathrm{K}^{+}$ & 0.95 & 1.60 & $\mathrm{SO}_{4}{ }^{2-}$ & 4.70 & 5.37 \\
\hline Available NPK (ppı & \multicolumn{5}{|c|}{ DTPA-extractable $\left(\mathrm{mg} \mathrm{kg}^{-1}\right)$} \\
\hline $\mathrm{N}$ & 18.21 & 21.32 & $\mathrm{Fe}$ & 1.76 & 1.82 \\
\hline $\mathrm{P}$ & 4.85 & 5.78 & $\mathrm{Mn}$ & 1.44 & 1.45 \\
\hline $\mathrm{K}$ & 63.45 & 73.20 & $\mathrm{Zn}$ & 0.37 & 0.50 \\
\hline
\end{tabular}

sample taken at the ripeness stage using an atomic absorption spectrophotometer as described by Page $\boldsymbol{e t}$ al. (1982). Samples of the plant were dried at $70^{\circ} \mathrm{C}$ for $50 \mathrm{hr}$., and digested using concentrated sulfuric and perchloric acid combination, $\left(1: 1 \mathrm{H}_{2} \mathrm{SO}_{4} / \mathrm{HClO}_{4}\right)$ Chapman and Pratt (1961). Fe, Mn and $\mathrm{Zn}$ were measured in straw and grain sample taken at the ripeness stage using an atomic absorption spectrophotometer according to Page et al. (1982).

The experimental design was split plot design with three replications, preceding crops were assigned to the main plots, while seven micronutrient treatments were allotted in subplots. The area of each experimental sub plot was $17.5 \mathrm{~m}^{2}$ ( $5 \mathrm{~m}$ in length and $3.5 \mathrm{~m}$ in width). This experiment included twenty one treatments which were the combinations of three preceding crops and seven treatments of micronutrients foliar application.

\section{A- Preceding crops of wheat were as follows:}

[1]- Fallow (control), [2]- Egyptian clover (Fahl) and [3]- Fodder maize.

\section{B- Micronutrients foliar applications of wheat plants were as follow:}

T1: $(\mathrm{Fe}+\mathrm{Zn}+\mathrm{Mn}) 3.36+4.20+3.36 \mathrm{~kg} \mathrm{fad}^{-1}$, $\mathrm{T} 2:(\mathrm{Fe}+\mathrm{Zn}) 3.36+4.20 \mathrm{~kg} \mathrm{fad}^{-1}$,

T3: $(\mathrm{Fe}+\mathrm{Mn}) 3.36+3.36 \mathrm{~kg}_{\text {fad. }}{ }^{-1}$, T4: Fe 3.36 kg fad. ${ }^{-1}, \mathrm{~T} 5:(\mathrm{Zn}+\mathrm{Mn}) 4.20+3.36 \mathrm{~kg}$ fad. $^{-1}$, T6: Zn $4.20 \mathrm{~kg} \mathrm{fad}^{-1}$, T7: Mn $3.36 \mathrm{~kg} \mathrm{fad}^{-1}$

Seven treatments from only micronutrient ( $\mathrm{Fe}, \mathrm{Zn}$ and $\mathrm{Mn}$ ) and combinations using 500 $\mathrm{mg} \mathrm{l}^{-1}$ for each with EDTA, $11 \%$ were carried out on the plants at 30,60 and 90 days after 
sowing. Spraying plants with tube well water at a level for one spray $1.12,1.12$ and $1.40 \mathrm{~kg}$ fad. ${ }^{1}$ from $\mathrm{FeSO}_{4}, \mathrm{MnSO}_{4}$ and $\mathrm{ZnSO}_{4}$, respectively.

In both growing seasons, all preceding crops were established following peanut (cv Giza 5). Peanut was growing on $15^{\text {th }}$ April and harvested on $1^{\text {st }}$ September in the two growing seasons. After peanut harvesting, the experimental area was divided to three main plots to occupy by fodder maize, Egyptian clover and fallow (control). Fodder maize and Egyptian clover were sown on $10^{\text {th }}$ September and harvested on $10^{\text {th }}$ November in both growing seasons. In the two growing seasons, peanut and clover seeds were inoculated by Bradyrhizobium and Rhizobium trifolii, respectively, before seeding it. All preceding summer crops were given their convention cultural practices. Wheat (cv. Gemmiza 11) was planted on $15^{\text {th }}$ November, meanwhile harvesting was done on $10^{\text {th }}$ April in both seasons. Phosphorus fertilizer was added at a level of $100 \mathrm{~kg} \mathrm{fad}^{-1}$ as mono calcium superphosphate $\left(15.5 \% \mathrm{P}_{2} \mathrm{O}_{5}\right)$ during soil preparation. Nitrogen was applied at a level of $100 \mathrm{~kg} \mathrm{fad}^{-1}$ as ammonium nitrate $(33.5 \% \mathrm{~N})$ in 4 equal doses every two weeks. Potassium fertilizer was applied at a level of $48 \mathrm{~kg} \mathrm{fad}^{-1}$ as potassium sulphate $\left(48 \% \quad \mathrm{~K}_{2} \mathrm{O}\right)$ at tillering and botting stage. All other cultural practices of growing wheat crop at Ismailia Governorate were followed as commendation.

At harvest, $1 \mathrm{~m}^{2}$ portion at the center of each wheat sub plot was sampled. From these samples, number of spikes/ $\mathrm{m}^{2}$ and grain yield Ardab fad ${ }^{-1}\left(\operatorname{Ardab}=150 \mathrm{~kg}\right.$ and $\left.\mathrm{fad}=4200 \mathrm{~m}^{2}\right)$ were determined. Plant height in $\mathrm{cm}$, No. of spikelets/spike, No. of grains/spike and 1000 grain weight $(\mathrm{g})$ were measured from 10 plants in each sub plots.

To calculate the net return of the different experimental treatments, the following market prices with Egyptian currency (LE) were used: $420 \mathrm{LE} /$ ardab for grain wheat, (Bulletin of The Agriculture Statistics, 2016/2017).

\section{Statistical Analysis}

Data obtained from each trail were subjected to analysis of variance (ANOVA) using the software of split plot design as described by Snedecor and Cochran (1981). Means of treatments were compared using the least significant differences (LSD) developed by Waller and Duncan (1969) at 5\% level.

\section{RESULTS AND DISCUSSION}

\section{Effect of Preceding Crops on Yield Components and Grain Yield of Wheat}

\section{Effect of preceding crops on yield components}

Results in Tables 2 and 3 and Fig. 1 clearly indicate that plant height, number of spikes $/ \mathrm{m}^{2}$, No. of spikelets/spike, No. of grains/spike and 1000 grain weight of wheat cv. Gemmiza 11 were significantly effected by the preceding crops and that was true in 2016/2017 and 2017/2018 seasons. All studied yield attributes of wheat (No. of spikes $/ \mathrm{m}^{2}$, No. of spikelets/ spike, No. of grains/spike and 1000 grain weight) achieved the highest values when wheat plants grown after Egyptian clover (354.95, $19.18,45.73$ and $45.18 \mathrm{~g}$ in the first season and $351.29,19.31,45.00$ and $41.66 \mathrm{~g}$ in the second season, respectively). While, cultivated wheat following fodder maize produced the lowest values of the previous mentioned traits. It is observed that fahl berseem was used as trap crop to capture left over $\mathrm{N}$ from the soil after peanut uprooting and improved total count of rhizobia that increased available soil $\mathrm{N}$ content and soil fertility as well as increased availability of micronutrients for wheat plant, as shown from chemical analysis of straw and grain wheat (Tables 4 and 5). These results are in the same context with those reported by Baldwin (2006) who mentioned that from 40 to 75 percent of the total $\mathrm{N}$ contained in a legume cover crop is available in the soil for subsequent crops, depending on environmental conditions. Less $\mathrm{N}$ uptake by legumes plants increased the $\mathrm{N}$ uptake by the following non-legume enhancing photosynthesis to increase photo assimilates translocation to different plant sinks and, in turn, enhancing yield and yield attributes (Khalil $\boldsymbol{e t}$ al., 2011). These results are in accordance with those obtained by Seif El-Nasr and Zahran (1998), Siadat et al. (2011), Gangaiah et al. (2012) and El-Mehy et al. (2014).

\section{Effect of preceding crops on grain yield}

Results illustrated in Tables 2 and 3 and Fig. 1 indicate that the preceding crops significantly affected on grain yield of wheat in both growing 
Table 2. Effect of preceding crops and foliar application of some micronutrients on yield and yield components of wheat in 2016/2017 season

\begin{tabular}{|c|c|c|c|c|c|c|c|}
\hline Man effect and interaction & $\begin{array}{c}\text { Plant } \\
\text { height } \\
\text { (cm) }\end{array}$ & $\begin{array}{c}\text { No. of } \\
\text { spikes/ } \\
\text { m }^{2}\end{array}$ & $\begin{array}{c}\text { No. of } \\
\text { spikelets } \\
\text { spike }\end{array}$ & $\begin{array}{c}\text { No. of } \\
\text { grains/ } \\
\text { spike }\end{array}$ & $\begin{array}{c}1000 \\
\text { grain } \\
\text { weight }(g)\end{array}$ & $\begin{array}{l}\text { Grain yield } \\
\text { (ardab/ } \\
\text { fad.) }\end{array}$ & $\begin{array}{c}\text { Straw } \\
\text { yield } \\
\text { (ton/fad.) }\end{array}$ \\
\hline Preceding crop (P) & \multicolumn{6}{|c|}{ First season $2016 / 2017$} & \\
\hline Fallow & $91.30 \mathrm{~b}$ & $347.90 \mathrm{~b}$ & $18.46 \mathrm{~b}$ & $44.55 \mathrm{~b}$ & $44.27 \mathrm{~b}$ & $17.08 \mathrm{~b}$ & $1.944 \mathrm{ab}$ \\
\hline Fahl clover & $92.77 \mathrm{a}$ & $354.95 \mathrm{a}$ & $19.18 \mathrm{a}$ & $45.73 \mathrm{a}$ & $45.18 \mathrm{a}$ & $18.18 \mathrm{a}$ & $2.059 \mathrm{a}$ \\
\hline Fodder maize & $89.72 \mathrm{c}$ & $341.33 \mathrm{c}$ & $17.70 \mathrm{c}$ & $44.34 \mathrm{~b}$ & $42.01 \mathrm{c}$ & $15.98 \mathrm{c}$ & $1.749 \mathrm{~b}$ \\
\hline LSD 0.05 & 0.33 & 1.00 & 0.26 & 0.22 & 0.06 & 0.11 & 0.12 \\
\hline \multicolumn{8}{|l|}{ Micronutrients (M) } \\
\hline $\mathbf{F e}+\mathrm{Zn}+\mathrm{Mn}$ & $92.14 \mathrm{a}$ & $353.67 \mathrm{a}$ & $18.71 \mathrm{a}$ & $46.04 \mathrm{a}$ & $44.22 \mathrm{a}$ & $17.64 \mathrm{a}$ & $1.979 \mathrm{a}$ \\
\hline $\mathbf{F e}+\mathbf{Z n}$ & $91.66 \mathrm{~b}$ & $352.22 \mathrm{ab}$ & $18.63 \mathrm{ab}$ & $45.24 \mathrm{~b}$ & $44.10 \mathrm{~b}$ & $17.49 \mathrm{ab}$ & $1.961 \mathrm{a}$ \\
\hline $\mathbf{F e}+\mathbf{M n}$ & $91.56 \mathrm{~b}$ & $350.11 \mathrm{ab}$ & $18.45 \mathrm{bc}$ & $45.14 \mathrm{bc}$ & $43.92 \mathrm{c}$ & $17.37 \mathrm{bc}$ & $1.948 \mathrm{ab}$ \\
\hline $\mathbf{F e}$ & $91.53 \mathrm{~b}$ & $349.22 \mathrm{~b}$ & $18.71 \mathrm{a}$ & $45.06 \mathrm{c}$ & $43.82 \mathrm{c}$ & $17.16 \mathrm{c}$ & $1.924 b$ \\
\hline $\mathbf{Z n}+\mathbf{M n}$ & $91.07 \mathrm{c}$ & $344.44 \mathrm{c}$ & $18.38 \mathrm{~cd}$ & $44.27 \mathrm{~d}$ & $43.67 \mathrm{~d}$ & $16.76 \mathrm{~d}$ & $1.891 \mathrm{c}$ \\
\hline $\mathbf{Z n}$ & $90.74 \mathrm{c}$ & $344.33 \mathrm{c}$ & $18.22 \mathrm{de}$ & $44.30 \mathrm{~d}$ & $43.64 \mathrm{~d}$ & $16.71 \mathrm{~d}$ & $1.879 \mathrm{c}$ \\
\hline Mn & $90.16 \mathrm{~d}$ & $342.44 \mathrm{c}$ & $18.02 \mathrm{e}$ & $44.06 \mathrm{e}$ & $43.30 \mathrm{e}$ & $16.42 \mathrm{e}$ & $1.842 \mathrm{~d}$ \\
\hline LSD 0.05 & 0.35 & 4.41 & 0.22 & 0.15 & 0.12 & 0.28 & 0.04 \\
\hline Interaction PxM & NS & NS & NS & NS & $*$ & NS & NS \\
\hline
\end{tabular}

Where: * and NS refers to significant at 0.5 and not significant, respectively.

Table 3. Effect of preceding crops and foliar application of some micronutrients on yield and yield components of wheat in $2017 / 2018$ season

\begin{tabular}{|c|c|c|c|c|c|c|c|}
\hline Man effect and interaction & $\begin{array}{l}\text { Plant } \\
\text { height } \\
\text { (cm) }\end{array}$ & $\begin{array}{c}\text { No. of } \\
\text { spikes/ } \\
\text { m }^{2} \\
\end{array}$ & $\begin{array}{c}\text { No. of } \\
\text { spikelets/ } \\
\text { spike }\end{array}$ & $\begin{array}{c}\text { No. of } \\
\text { grains/ } \\
\text { spike }\end{array}$ & $\begin{array}{c}1000 \\
\text { grain } \\
\text { weight }(\mathrm{g}) \\
\end{array}$ & $\begin{array}{l}\text { Grain yield } \\
\text { (ardab/ } \\
\text { fad.) }\end{array}$ & $\begin{array}{c}\text { Straw } \\
\text { yield } \\
\text { (ton/fad.) }\end{array}$ \\
\hline Preceding crop (P) & \multicolumn{6}{|c|}{ Second season $2017 / 2018$} & \\
\hline Fallow & $91.89 \mathrm{~b}$ & $345.43 \mathrm{~b}$ & $18.59 \mathrm{~b}$ & $44.02 \mathrm{~b}$ & $40.66 \mathrm{~b}$ & $16.51 \mathrm{~b}$ & $1.822 \mathrm{~b}$ \\
\hline Fahl clover & $94.46 \mathrm{a}$ & $351.29 \mathrm{a}$ & $19.31 \mathrm{a}$ & $45.00 \mathrm{a}$ & $41.66 \mathrm{a}$ & $17.68 \mathrm{a}$ & $2.010 \mathrm{a}$ \\
\hline Fodder maize & $89.28 \mathrm{c}$ & $330.62 \mathrm{c}$ & $17.62 \mathrm{c}$ & $42.81 \mathrm{c}$ & $39.40 \mathrm{c}$ & $15.66 \mathrm{c}$ & $1.769 \mathrm{bc}$ \\
\hline LSD 0.05 & 0.28 & 1.68 & 0.097 & 0.25 & 0.13 & 0.11 & 0.11 \\
\hline \multicolumn{8}{|l|}{ Micronutrients (M) } \\
\hline $\mathbf{F e}+\mathbf{Z n}+\mathbf{M n}$ & $93.47 \mathrm{a}$ & $355.44 \mathrm{a}$ & $18.82 \mathrm{a}$ & $44.28 \mathrm{a}$ & $41.63 \mathrm{a}$ & $17.51 \mathrm{a}$ & $1.956 \mathrm{a}$ \\
\hline $\mathbf{F e}+\mathbf{Z n}$ & $92.74 \mathrm{~b}$ & $349.44 \mathrm{~b}$ & $18.68 \mathrm{~b}$ & $44.22 \mathrm{a}$ & $41.22 \mathrm{~b}$ & $17.17 \mathrm{~b}$ & $1.933 \mathrm{a}$ \\
\hline $\mathbf{F e}+\mathbf{M n}$ & $92.54 \mathrm{~b}$ & $344.89 \mathrm{c}$ & $18.63 \mathrm{bc}$ & $44.34 \mathrm{a}$ & $40.80 \mathrm{c}$ & $17.04 \mathrm{c}$ & $1.923 \mathrm{a}$ \\
\hline $\mathbf{F e}$ & $92.02 \mathrm{c}$ & $346.55 \mathrm{bc}$ & $18.53 \mathrm{c}$ & $44.01 \mathrm{~b}$ & $40.57 \mathrm{~d}$ & $16.97 \mathrm{c}$ & $1.911 \mathrm{a}$ \\
\hline $\mathbf{Z n}+\mathbf{M n}$ & $90.45 \mathrm{e}$ & $337.89 \mathrm{~d}$ & $18.32 \mathrm{~d}$ & $43.71 \mathrm{c}$ & 39.92 ef & $16.07 \mathrm{~d}$ & $1.853 \mathrm{ab}$ \\
\hline Zn & $90.92 \mathrm{~d}$ & $333.67 \mathrm{e}$ & $18.38 \mathrm{~d}$ & $43.63 \mathrm{c}$ & $40.07 \mathrm{e}$ & $15.95 \mathrm{e}$ & $1.838 \mathrm{~b}$ \\
\hline Mn & $90.99 \mathrm{~d}$ & $329.22 \mathrm{f}$ & $18.19 \mathrm{e}$ & $43.42 \mathrm{~d}$ & $39.80 \mathrm{f}$ & $15.65 \mathrm{f}$ & $1.763 \mathrm{c}$ \\
\hline LSD 0.05 & 0.20 & 3.06 & 0.11 & 0.21 & 0.18 & 0.14 & 0.10 \\
\hline Interaction PxM & $*$ & * & NS & * & * & * & NS \\
\hline
\end{tabular}

Where: * and NS refers to significant at 0.5 and not significant, respectively. 
Abd Allah, et al.
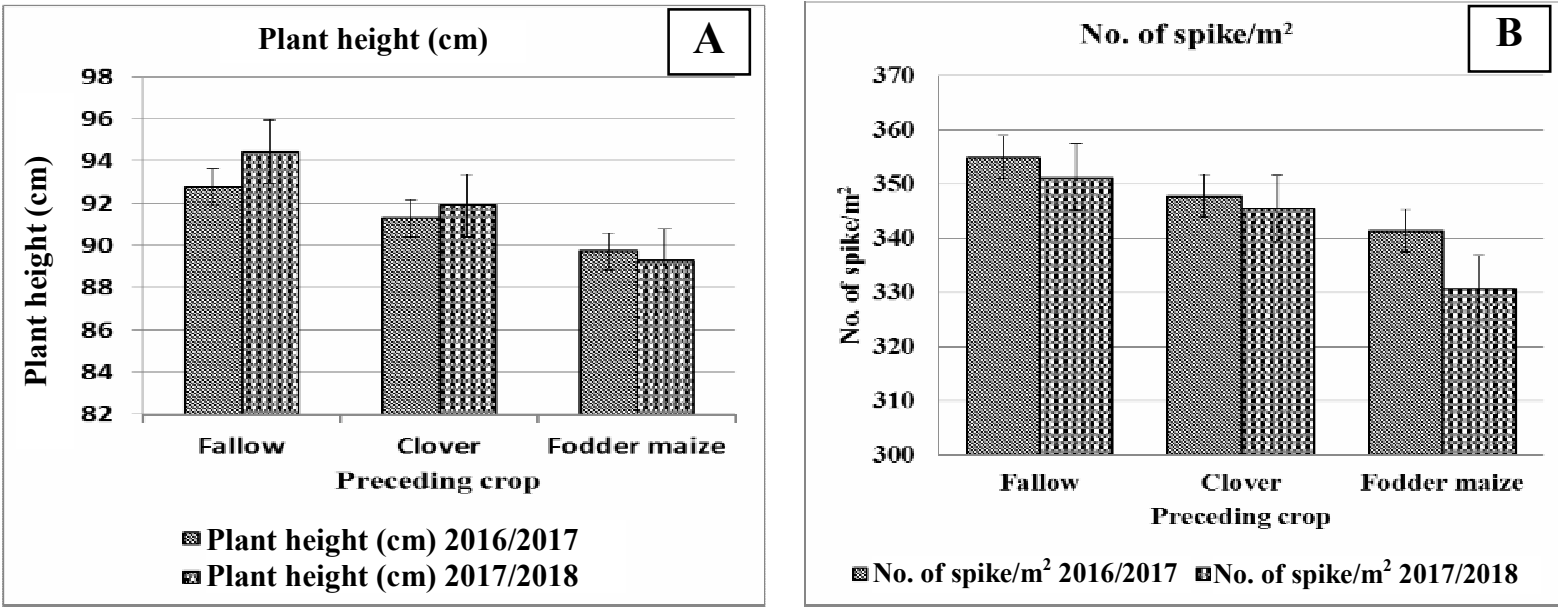

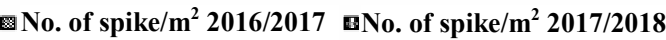
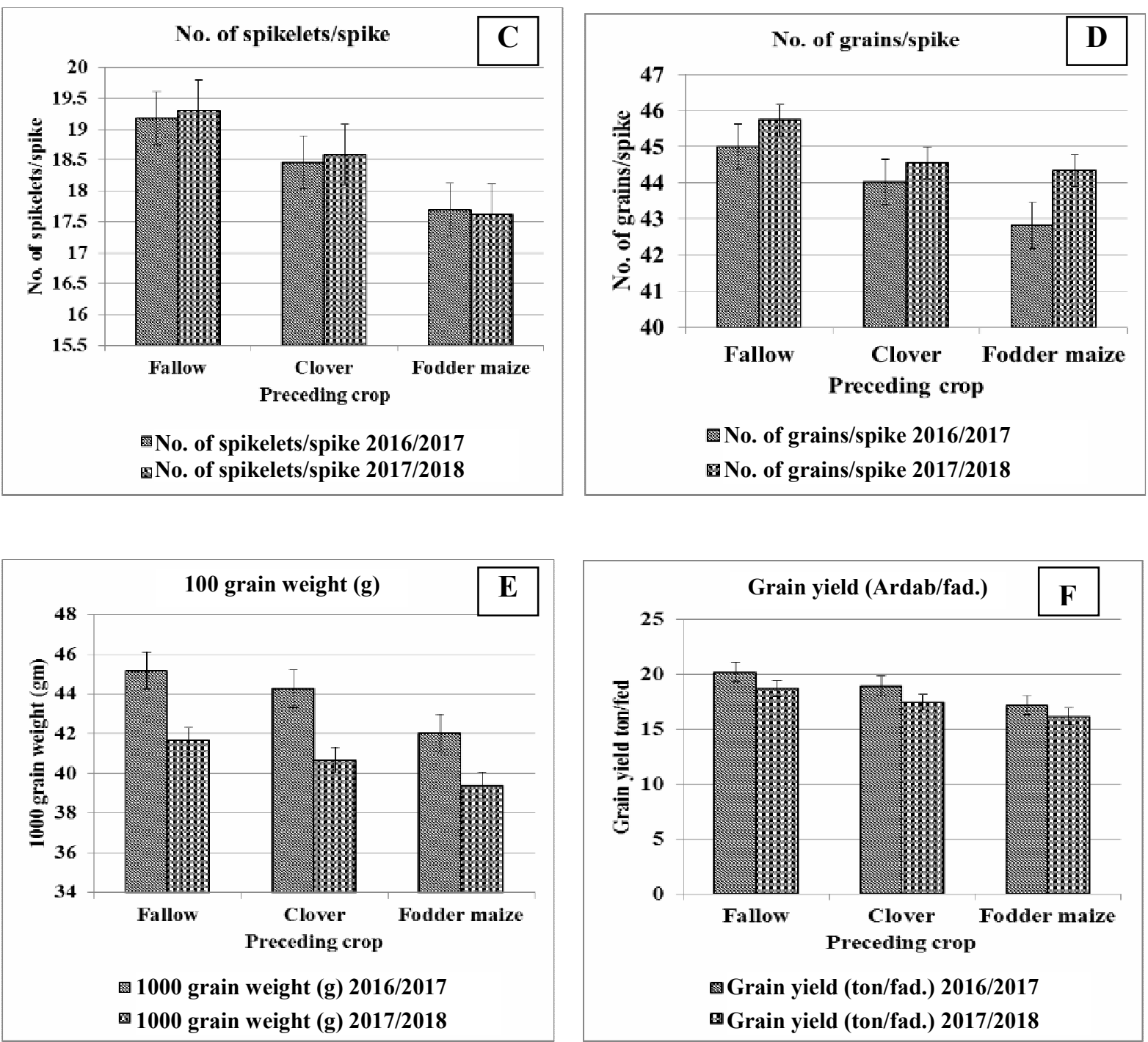

Fig. 1. Effect of preceding crop on plant height (A), No.of spike/m² (B), No. of spikletes/spike (C), No. of grains/spike (D), 1000 grain weight (E) and grain yield ardab/fad (F) of wheat in 2016/2017 and 2017/2018 seasons 
seasons and had the same trend of yield components. The highest average grain yield were 18.18 and $17.68 \mathrm{Ardab} / \mathrm{fad}$., when wheat grown after fahl clover followed by wheat grown after fallow (17.08 and 16.51 Ardab/ fad.), while the lowest values were recorded when wheat was sown after fodder maize (15.98 and 15.66 Ardab/fad.) during $1^{\text {st }}$ and $2^{\text {nd }}$ seasons, respectively. Grain yield/fad., of wheat plants grown after clover surpassed those grown after fallow and fodder maize by 6.44 and $13.76 \%$ in the first season and by 7.09 and $12.90 \%$ in the second one, respectively. Similarly, growing wheat following fahl clover significantly increased straw yield by 5.92 and $17.72 \%$ in $2016 / 2017$ and by 10.32 and $13.62 \%$ in $2017 / 2018$ season, respectively. This superiority of wheat grown after fahl clover may be attributed to the highest values of most of yield components such as spike length, number of spikes/plant. That indicated that growing fahl clover following peanut during the transition period season can immobilize soil $\mathrm{N}$ (fixing by peanut) in the plant biomass in addition to adding $\mathrm{N}$ from the atmosphere and reduced $\mathrm{N}$ losses by both leaching and denitrification (Pandey et al., 2008), increased avialbility of micronutrients. Inclusion of legumes increases soil fertility and consequently the productivity of succeeding cereal crops (Ghosh et al., 2007). Results are in agreement with those obtained by Seif El-Nasr and Zahran (1998), AbouKerisha (1998), Badr (1999), Siadat et al. (2011), Gangaiah et al. (2012), Maadi et al. (2012) and El-Mehy et al. (2014).

\section{Effect of Micronutrients on Yield Components and Grain Yield of Wheat}

Effect of micronutrients on yield components

Results in Table 2 and 3 show that plant height $(\mathrm{cm})$, number of spikes $/ \mathrm{m}^{2}$, No. of spikelets/spike, No. of grains/spike and 1000 grain weight $(\mathrm{g})$ of wheat plant significantly increased due to the foliar application of mixed three micronutrients $(\mathrm{Fe}, \mathrm{Zn}$ and $\mathrm{Mn})$. These results are true in 2016/2017 and 2017/2018 seasons. The highest value for each of these traits was obtained when mixed spray of the three micronutrients $(\mathrm{Fe}+\mathrm{Mn}+\mathrm{Zn})$ was conducted together and that was true in the two growing seasons. The lowest value for each of these traits was achieved from individual application of $\mathrm{Mn}$ or $\mathrm{Zn}$ followed by application of $\mathrm{Mn}+\mathrm{Zn}$. Iron has a structural role in chlorophyll, energy transfer within the plant and enters in root cells. This in turn, may be leads to an increase in yield components of wheat plants. These results are in agreement with Reddy (2004), Chaudry et al. (2007), Zain et al. (2015) and Aziz et al. (2019). This increase may be taken place mainly due to the additional availability of micronutrients of wheat plants. In this respect, Grewal et al. (1997) reported that wheat production increased with application of $\mathrm{Zn}$ and boron. In this context, Gueins et al. (2003) reported significant increase in number of grains/spike and 1000-grain weight of wheat due to foliar application of boron and zinc. Chaudry et al. (2007) reported that micronutrients ( $\mathrm{Zn}$ and $\mathrm{Fe})$ significantly increased the wheat yield over control. Also, Chowdhury et al. (2008) revealed that application of micronutrients (soil + foliar) was the best method to increase grain yield of wheat. Therefore, by supplying plants with micronutrients, either through soil application, foliar spray or side dressing, the quality and yield of crops is improved (Malakouti, 2008).

\section{Effect of micronutrients on grain yield}

Mixed foliar application of $\mathrm{Fe}, \mathrm{Zn}$ and $\mathrm{Mn}$ had significant increase in grain yield and that was true in the both growing seasons (Tables 2 and 3). Obvious significant increases were recorded for grain yield with foliar mixture application of micronutrients $(\mathrm{Fe}+\mathrm{Zn}+\mathrm{Mn})$ over than the individual $\mathrm{Fe}, \mathrm{Zn}$ and $\mathrm{Mn}$ by 2.80 , 5.57 and $7.43 \%$ in the first seasons and 3.18 , 9.78 and $11.88 \%$ in the second season, respectively. This increase may be attributed to the additional availability of micronutrients of wheat plants. In this respect, Grewal et al. (1997) reported that wheat production increased with application of $\mathrm{Zn}$ and boron. In this context, Gueins et al. (2003) reported significant increase in number of grains/spike and 1000-grain weight of wheat due to foliar application of boron and zinc. 
In both seasons, straw yield behaved the same trend of grain yield/fad., due to micronutrients foliar application. Applying mixed of $\mathrm{Fe}+\mathrm{Zn}+\mathrm{Mn}$ micronutrients significantly increased straw yield ton/fad., comparative to individual spray of $\mathrm{Fe}, \mathrm{Zn}$ and Mn by 2.86, 5.32 and $7.44 \%$ and were $2.35,6.42$ and $10.95 \%$ in the first and the second seasons, respectively. These results are in accordance with those obtained by Chaudry et al. (2007) who reported that micronutrients $(\mathrm{Zn}$ and $\mathrm{Fe}$ ) significantly increased the wheat yield over control. Also, Chowdhury et al. (2008) revealed that application of micronutrients (soil + foliar) was the best method to increase grain yield of wheat. Therefore, by supplying plants with micronutrients, either through soil application, foliar spray or side dressing, the quality and yield of crops is improved (Malakouti, 2008).

\section{Chemical Composition of Straw and Grain Wheat (Fe, Mn and Zn)}

Results in Tables 4 and 5 show that growing wheat after peanut/clover produced the highest micronutrients concentration in straw and grain, were $\mathrm{Fe}\left(147.4\right.$ and $\left.121.0 \mathrm{mg} \mathrm{kg}^{-1}\right), \mathrm{Mn}(22.5$ and $\left.18.7 \mathrm{mg} \mathrm{kg}^{-1}\right)$, and $\mathrm{Zn}\left(31.6\right.$ and $\left.25.9 \mathrm{mg} \mathrm{kg}^{-1}\right)$ in the first season 2016/2017, whereas in the second season (2017/2018) were Fe (168.0 and $\left.125.7 \mathrm{mg} \mathrm{kg}^{-1}\right), \mathrm{Mn}$ (29.1 and $\left.23.1 \mathrm{mg} \mathrm{kg}^{-1}\right)$, and $\mathrm{Zn}\left(34.9\right.$ and $\left.30.5 \mathrm{mg} \mathrm{kg}^{-1}\right)$, respectively. While the lowest values of these traits were obtained by growing wheat following peanut/ fallow in both seasons. These results indicated that clover as preceding crops left good residual effect on wheat components (grain and straw) which gave the highest concentration of micronutrients (Fe, $\mathrm{Zn}$ and $\mathrm{Mn}$ ).

With respect to foliar application by micronutrients, results indicated that the highest values of micronutrients concentration in straw and grain were $\mathrm{Fe}$ (228.6 and $\left.246.6 \mathrm{mg} \mathrm{kg}^{-1}\right), \mathrm{Mn}$ (34.3 and $29.7 \mathrm{mg} \mathrm{kg}^{-1}$ ), and $\mathrm{Zn}$ (44.5 and $\left.39.3 \mathrm{mgkg}^{-1}\right)$ respectively, while in the second season were $\mathrm{Fe}$ (292.1 and $\left.202.8 \mathrm{mg} \mathrm{kg}^{-1}\right), \mathrm{Mn}$ (40.0 and $35.8 \mathrm{mg} \mathrm{kg}^{-1}$ ), and $\mathrm{Zn} \mathrm{(48.3} \mathrm{and}$ $42.4 \mathrm{mgkg}^{-1}$ ) respectively obtained by the foliar spray $\mathrm{Fe}+\mathrm{Mn}+\mathrm{Zn}$ treatment. It is worth to noting that, $\mathrm{Zn}$ spray positively effect on $\mathrm{Fe}$ and $\mathrm{Zn}$ content in wheat straw and grain but negatively effect on $\mathrm{Mn}$ content in wheat. The effect of application these micronutrients may be attributed to the essential role of them in the biological processes via their functions in enzymes activities in plants. These results are in an agreement with those obtained by Assaf $\boldsymbol{e t} \boldsymbol{a l}$. (2007), Maralian (2009) and Yangx et al. (2016).

\section{Interaction Effect}

Results in Table 6 reveal that interaction effect between preceding crops and micronutrients application had significant effect on plant height, No. of spikes $/ \mathrm{m}^{2}$, No. of grains/ spike and grain yield ardab fad ${ }^{-1}$ only in the second season and 1000 grain weight in both seasons, while No. of spikelets/spike, straw yield/fad., and $\mathrm{Fe}, \mathrm{Mn}$ and $\mathrm{Zn}$ concentration of straw and grain were insignificantly affected in both seasons. The micronutrients contents of wheat grain and shoot significant affected by foliar application of micronutrients and the highest values of the mentioned traits were achieved when growing wheat after clover and applied mixture of micronutrient $(\mathrm{Fe}+\mathrm{Zn}+\mathrm{Mn})$, whereas the lowest values of these traits were obtained by growing wheat after fodder maize and foliar application by $\mathrm{Mn}$ lonely. These results were expected since growing fahl clover as a preceding crop improved soil fertility, which increased growth, yield components and grain yield of wheat. Similarly, supplying plants with micronutrients, foliar spray, the quality and yield of crops is improved. Similar results are obtained by Malakouti (2008), Maralian (2009) and Yangx et al. (2016).

\section{Economic Evaluation}

Results tabulated in Table 7 show that total and net incomes of grain and straw yields markedly increased when growing wheat after clover in both seasons. The highest total and net incomes (8922 and $1868 \mathrm{LE} \mathrm{fad}^{-1}$ ) in the first and (8629 and $\left.1625 \mathrm{LE} \mathrm{fad}^{-1}\right)$ in the second season, respectively, were obtained by including clover as a preceding crop of wheat. Growing clover in transition period between peanut and wheat increased net income of wheat by 40.03 and $53.74 \%$ comparison to fallow. This indicated that the vital role of legumes in increases soil fertility and consequently the productivity of succeeding cereal crops. This result supported by El-Mehy et al. (2014) they found that Fahl berseem as preceding crops for wheat recorded 
Table 4. Effect of preceding crop and foliar application of some micronutrients on $\mathrm{Fe}, \mathrm{Mn}$ and $\mathrm{Zn}$ concentration ( $\left.\mathrm{mg} \mathrm{kg}^{-1}\right)$ of wheat straw grown on a sandy soil in the two growing seasons

\begin{tabular}{lcccccc}
\hline Man effect and interaction & \multicolumn{3}{c}{ First season 2016/2017 } & \multicolumn{3}{c}{ Second season 2017/2018 } \\
\cline { 2 - 7 } & $\begin{array}{c}\mathbf{F e} \\
\left(\mathbf{m g ~ k g}^{-1}\right)\end{array}$ & $\begin{array}{c}\mathbf{M n} \\
\left(\mathbf{m g ~ k g}^{-1}\right)\end{array}$ & $\begin{array}{c}\mathbf{Z n} \\
\left(\mathbf{m g ~ k g}^{-1}\right)\end{array}$ & $\begin{array}{c}\mathbf{F e} \\
\left(\mathbf{m g ~ k g}^{-1}\right)\end{array}$ & $\begin{array}{c}\mathbf{M n} \\
\left(\mathbf{m g ~ k g}^{-1}\right)\end{array}$ & $\begin{array}{c}\mathbf{Z n} \\
\left(\mathbf{m g ~ k g}^{-1}\right)\end{array}$ \\
\hline Preceding crop (P) & & & & & & \\
Fallow & 125.2 & 20.1 & 22.3 & 130.6 & 25.5 & 26.8 \\
Fahl clover & 147.4 & 22.5 & 31.6 & 168.0 & 29.1 & 34.9 \\
Fodder maize & 123.8 & 19.4 & 20.5 & 128.5 & 21.4 & 24.5 \\
LSD 0.05 & 9.7 & 1.3 & 3.1 & 7.6 & 1.4 & 2.1 \\
Micronutrients (M) & & & & & & \\
Fe+Zn+Mn & 228.6 & 34.3 & 44.5 & 292.1 & 40.0 & 48.3 \\
$\mathbf{F e}+\mathbf{Z n}$ & 175.8 & 23.2 & 38.7 & 199.5 & 28.3 & 45.0 \\
$\mathbf{F e}+\mathbf{M n}$ & 192.7 & 31.2 & 29.8 & 215.3 & 38.1 & 29.3 \\
Fe & 168.5 & 23.5 & 21.5 & 196.5 & 26.8 & 24.9 \\
$\mathbf{Z n}+\mathbf{M n}$ & 153.4 & 27.0 & 37.2 & 189.0 & 34.5 & 40.7 \\
$\mathbf{Z n}$ & 132.2 & 21.4 & 35.8 & 147.9 & 24.5 & 44.3 \\
Mn & 145.5 & 29.2 & 20.3 & 161.2 & 35.2 & 23.8 \\
Man & 141.9 & 25.18 & 30.22 & 182.9 & 30.34 & 34.25 \\
LSD 0.05 & 19.8 & 4.6 & 5.2 & 22.5 & 5.8 & 7.1 \\
Interaction & & & & & & \\
$\mathbf{P ~ x ~ M ~}$ & 20.1 & 3.5 & 5.4 & 12.6 & 4.2 & 6.3 \\
\hline Where: *and NS refers to significant at 0.5 and not significant, respectively. &
\end{tabular}

Where: * and NS refers to significant at 0.5 and not significant, respectively.

Table 5. Effect of preceding crop and foliar application of some micronutrients on $\mathrm{Fe}, \mathrm{Mn}$ and $\mathrm{Zn}$ concentration $\left(\mathrm{mg} \mathrm{kg}^{-1}\right)$ of wheat grain grown on a sandy soil in the two growing seasons

\begin{tabular}{|c|c|c|c|c|c|c|}
\hline \multirow[t]{2}{*}{ Man effect and interaction } & \multicolumn{3}{|c|}{ First season 2016/2017 } & \multicolumn{3}{|c|}{ Second season 2017/2018 } \\
\hline & $\begin{array}{c}\mathrm{Fe} \\
\left(\mathrm{mg} \mathrm{kg}^{-1}\right)\end{array}$ & $\begin{array}{c}\mathrm{Mn} \\
\left(\mathrm{mg} \mathrm{kg}^{-1}\right)\end{array}$ & $\begin{array}{c}\mathrm{Zn} \\
\left(\mathrm{mg} \mathrm{kg}^{-1}\right)\end{array}$ & $\begin{array}{c}\mathrm{Fe} \\
\left(\mathrm{mg} \mathrm{kg}^{-1}\right)\end{array}$ & $\begin{array}{c}\mathrm{Mn} \\
\left(\mathrm{mg} \mathrm{kg}^{-1}\right)\end{array}$ & $\begin{array}{c}\mathrm{Zn} \\
\left(\mathrm{mg} \mathrm{kg}^{-1}\right)\end{array}$ \\
\hline \multicolumn{7}{|l|}{$\overline{\text { Preceding crop (P) }}$} \\
\hline Fallow & 105.7 & 15.8 & 15.5 & 109.6 & 19.7 & 21.3 \\
\hline Clover & 121.0 & 18.7 & 25.9 & 125.7 & 23.1 & 30.5 \\
\hline Fodder maize & 101.6 & 14.6 & 14.8 & 106.5 & 17.0 & 33.4 \\
\hline LSD 0.05 & 8.4 & 1.3 & 2.3 & 9.0 & 1.6 & 1.7 \\
\hline \multicolumn{7}{|l|}{ Micronutrients (M) } \\
\hline $\mathrm{Fe}+\mathrm{Zn}+\mathrm{Mn}$ & 246.6 & 29.7 & 39.3 & 202.8 & 35.8 & 42.4 \\
\hline $\mathrm{Fe}+\mathrm{Zn}$ & 162.3 & 18.1 & 34.5 & 169.2 & 22.6 & 38.7 \\
\hline $\mathrm{Fe}+\mathrm{Mn}$ & 168.0 & 26.9 & 16.3 & 175.1 & 33.2 & 24.5 \\
\hline $\mathrm{Fe}$ & 164.5 & 17.7 & 16.4 & 170.0 & 21.7 & 19.8 \\
\hline $\mathrm{Zn}+\mathrm{Mn}$ & 131.4 & 23.8 & 32.6 & 134.1 & 30.0 & 37.0 \\
\hline $\mathrm{Zn}$ & 114.5 & 16.5 & 31.2 & 118.0 & 20.7 & 34.6 \\
\hline $\mathrm{Mn}$ & 117.5 & 25.4 & 16.0 & 124.4 & 32.1 & 21.3 \\
\hline Mean & 143.3 & 20.72 & 24.25 & 143.5 & 25.57 & 29.35 \\
\hline LSD 0.05 & 18.1 & 2.6 & 6.4 & 17.3 & 4.2 & 6.0 \\
\hline \multicolumn{7}{|l|}{ Interaction } \\
\hline $\mathbf{P} \times \mathbf{M}$ & 19.7 & 3.1 & 5.2 & 25.6 & 4.7 & 3.4 \\
\hline
\end{tabular}


Table 6. Effect of the interaction between preceding crops and foliar application of some micronutrients on wheat traits in the two growing seasons

\begin{tabular}{|c|c|c|c|c|c|c|}
\hline \multirow[t]{3}{*}{ Mixture micronutrient } & \multicolumn{3}{|c|}{ First season 2016/2017 } & \multicolumn{3}{|c|}{ Second season $2017 / 2018$} \\
\hline & \multicolumn{6}{|c|}{ Preceding crop } \\
\hline & Fallow & Clover & Fodder maize & Fallow & Clover & Fodder maize \\
\hline & \multicolumn{6}{|c|}{ Plant height (cm) } \\
\hline $\mathrm{Fe}+\mathrm{Zn}+\mathrm{Mn}$ & 92.20 & 93.63 & 90.60 & 93.06 & 96.02 & 91.32 \\
\hline $\mathrm{Fe}+\mathrm{Zn}$ & 91.60 & 93.20 & 90.17 & 92.54 & 95.73 & 89.93 \\
\hline $\mathrm{Fe}+\mathrm{Mn}$ & 91.80 & 92.90 & 89.97 & 92.09 & 95.41 & 90.12 \\
\hline $\mathrm{Fe}$ & 91.17 & 92.93 & 90.50 & 92.03 & 95.11 & 88.93 \\
\hline $\mathrm{Zn}+\mathrm{Mn}$ & 91.10 & 92.53 & 89.57 & 90.42 & 92.62 & 88.32 \\
\hline $\mathrm{Zn}$ & 91.07 & 92.40 & 88.77 & 91.51 & 93.24 & 88.00 \\
\hline $\mathrm{Mn}$ & 90.17 & 91.80 & 88.50 & 91.54 & 93.09 & 88.33 \\
\hline \multirow[t]{2}{*}{ LSD 0.05} & \multicolumn{3}{|c|}{ NS } & \multicolumn{3}{|c|}{0.35} \\
\hline & \multicolumn{6}{|c|}{ No. of spikes $/ \mathrm{m}^{2}$} \\
\hline $\mathrm{Fe}+\mathrm{Zn}+\mathrm{Mn}$ & 354.33 & 361.33 & 345.33 & 357.67 & 360.00 & 348.67 \\
\hline $\mathrm{Fe}+\mathrm{Zn}$ & 351.67 & 359.00 & 346.00 & 352.33 & 357.67 & 338.33 \\
\hline $\mathrm{Fe}+\mathrm{Mn}$ & 349.00 & 355.00 & 346.33 & 350.00 & 353.67 & 331.00 \\
\hline $\mathrm{Fe}$ & 345.67 & 359.67 & 342.33 & 348.33 & 354.67 & 336.67 \\
\hline $\mathrm{Zn}+\mathrm{Mn}$ & 342.67 & 352.00 & 338.67 & 340.33 & 349.33 & 324.00 \\
\hline $\mathrm{Zn}$ & 346.33 & 349.00 & 337.67 & 337.01 & 342.70 & 321.34 \\
\hline $\mathrm{Mn}$ & 345.67 & 348.67 & 333.00 & 332.33 & 341.00 & 314.33 \\
\hline \multirow[t]{2}{*}{ LSD 0.05} & \multicolumn{3}{|c|}{ NS } & \multicolumn{3}{|c|}{5.30} \\
\hline & \multicolumn{6}{|c|}{ No. of grains/spike } \\
\hline $\mathrm{Fe}+\mathrm{Zn}+\mathrm{Mn}$ & 44.37 & 45.47 & 43.00 & 46.03 & 46.77 & 45.33 \\
\hline $\mathrm{Fe}+\mathrm{Zn}$ & 44.27 & 45.37 & 43.03 & 44.67 & 46.43 & 44.63 \\
\hline $\mathrm{Fe}+\mathrm{Mn}$ & 44.30 & 45.43 & 43.30 & 44.50 & 46.40 & 44.53 \\
\hline $\mathrm{Fe}$ & 44.10 & 45.03 & 42.90 & 44.77 & 46.03 & 44.37 \\
\hline $\mathrm{Zn}+\mathrm{Mn}$ & 43.73 & 44.83 & 42.57 & 43.97 & 44.73 & 44.10 \\
\hline $\mathrm{Zn}$ & 43.77 & 44.60 & 42.53 & 44.12 & 45.04 & 43.75 \\
\hline $\mathrm{Mn}$ & 43.63 & 44.27 & 42.37 & 43.80 & 44.70 & 43.67 \\
\hline LSD 0.05 & \multicolumn{3}{|c|}{ NS } & \multicolumn{3}{|c|}{0.25} \\
\hline
\end{tabular}


Zagazig J. Agric. Res., Vol. 47 No. (2) 2020

Table 6. Cont. Effect of interaction between preceding crops and foliar application of some micronutrients on wheat traits in the two growing seasons

\begin{tabular}{|c|c|c|c|c|c|c|}
\hline \multirow{3}{*}{$\begin{array}{l}\text { Mixture micronutrient } \\
\mathrm{Fe}+\mathrm{Zn}+\mathrm{Mn}\end{array}$} & \multicolumn{6}{|c|}{ Preceding crop } \\
\hline & \multicolumn{6}{|c|}{1000 grain weight $(g)$} \\
\hline & 44.36 & 45.46 & 43.00 & 41.80 & 42.66 & 40.43 \\
\hline $\mathrm{Fe}+\mathrm{Zn}$ & 44.26 & 45.36 & 43.03 & 41.16 & 42.50 & 40.00 \\
\hline $\mathrm{Fe}+\mathrm{Mn}$ & 44.30 & 45.43 & 43.30 & 40.66 & 41.86 & 39.86 \\
\hline $\mathrm{Fe}$ & 44.10 & 45.03 & 42.90 & 40.46 & 41.83 & 39.40 \\
\hline $\mathrm{Zn}+\mathrm{Mn}$ & 43.73 & 44.83 & 42.56 & 40.26 & 41.03 & 38.46 \\
\hline $\mathrm{Zn}$ & 43.76 & 44.60 & 42.53 & 40.10 & 41.03 & 39.06 \\
\hline $\mathrm{Mn}$ & 43.63 & 44.26 & 42.36 & 40.13 & 40.70 & 38.56 \\
\hline \multirow[t]{2}{*}{ LSD 0.05} & & 0.21 & & & 0.31 & \\
\hline & \multicolumn{6}{|c|}{ Grain yield (Ardab fad..$^{-1}$ ) } \\
\hline $\mathrm{Fe}+\mathrm{Zn}+\mathrm{Mn}$ & 17.65 & 18.83 & 16.44 & 17.54 & 18.69 & 16.30 \\
\hline $\mathrm{Fe}+\mathrm{Zn}$ & 17.49 & 18.62 & 16.37 & 17.20 & 18.28 & 16.05 \\
\hline $\mathrm{Fe}+\mathrm{Mn}$ & 17.24 & 18.40 & 16.48 & 16.81 & 18.25 & 16.07 \\
\hline $\mathrm{Fe}$ & 17.01 & 18.40 & 16.08 & 16.75 & 18.15 & 15.99 \\
\hline $\mathrm{Zn}+\mathrm{Mn}$ & 16.67 & 17.92 & 15.69 & 15.96 & 17.07 & 15.17 \\
\hline $\mathrm{Zn}$ & 16.83 & 17.67 & 15.62 & 15.79 & 16.76 & 15.31 \\
\hline $\mathrm{Mn}$ & 16.67 & 17.43 & 15.17 & 15.54 & 16.52 & 14.89 \\
\hline \multirow[t]{2}{*}{ LSD 0.05} & & NS & & & 0.27 & \\
\hline & \multicolumn{6}{|c|}{ Straw yield (Ton fad. ${ }^{-1}$ ) } \\
\hline $\mathrm{Fe}+\mathrm{Zn}+\mathrm{Mn}$ & 2.002 & 2.133 & 1.800 & 1.948 & 2.084 & 1.837 \\
\hline $\mathrm{Fe}+\mathrm{Zn}$ & 1.981 & 2.110 & 1.794 & 1.934 & 2.049 & 1.816 \\
\hline $\mathrm{Fe}+\mathrm{Mn}$ & 1.953 & 2.084 & 1.807 & 1.919 & 2.067 & 1.783 \\
\hline $\mathrm{Fe}$ & 1.925 & 2.084 & 1.763 & 1.860 & 2.049 & 1.824 \\
\hline $\mathrm{Zn}+\mathrm{Mn}$ & 1.921 & 2.029 & 1.721 & 1.848 & 1.962 & 1.749 \\
\hline $\mathrm{Zn}$ & 1.940 & 2.001 & 1.696 & 1.865 & 1.942 & 1.706 \\
\hline $\mathrm{Mn}$ & 1.888 & 1.974 & 1.663 & 1.798 & 1.914 & 1.667 \\
\hline LSD 0.05 & & NS & & & NS & \\
\hline
\end{tabular}


Table 7. Net income (LE fad. $\left.{ }^{-1}\right)$ of grain wheat as affected by the interaction of a preceding crops and foliar application of some micronutrients in both growing seasons

\begin{tabular}{|c|c|c|c|c|c|c|c|c|}
\hline \multirow[t]{3}{*}{ Mixture micronutrient } & \multicolumn{4}{|c|}{ First season 2016/2017 } & \multicolumn{4}{|c|}{ Second season $2017 / 2018$} \\
\hline & \multicolumn{8}{|c|}{ Total income (LE/fad.) } \\
\hline & Fallow & Clover & Fodder maize & Mean & Fallow & Clover & Fodder maize & Mean \\
\hline $\mathrm{Fe}+\mathrm{Zn}+\mathrm{Mn}$ & 8664 & 9240 & 8028 & 8644 & 8584 & 9152 & 7992 & 8576 \\
\hline $\mathrm{Fe}+\mathrm{Zn}$ & 8582 & 9139 & 7993 & 8571 & 8430 & 8958 & 7873 & 8420 \\
\hline $\mathrm{Fe}+\mathrm{Mn}$ & 8462 & 9028 & 8048 & 8513 & 8258 & 8956 & 7863 & 8359 \\
\hline $\mathrm{Fe}$ & 8347 & 9028 & 7853 & 8409 & 8195 & 8905 & 7857 & 8319 \\
\hline $\mathrm{Zn}+\mathrm{Mn}$ & 8202 & 8794 & 7663 & 8219 & 7859 & 8397 & 7465 & 7907 \\
\hline $\mathrm{Zn}$ & 8282 & 8670 & 7619 & 8190 & 7799 & 8253 & 7495 & 7849 \\
\hline $\mathrm{Mn}$ & 8180 & 8555 & 7407 & 8048 & 7652 & 8136 & 7294 & 7694 \\
\hline Mean & 8388 & 8922 & 7802 & & 8111 & 8679 & 7691 & \\
\hline \multirow[t]{2}{*}{ Treatments } & \multicolumn{8}{|c|}{ Net income (LE/fad.) } \\
\hline & Fallow & Clover & Fodder maize & Mean & Fallow & Clover & Fodder maize & Mean \\
\hline $\mathrm{Fe}+\mathrm{Zn}+\mathrm{Mn}$ & 1610 & 2186 & 974 & 1590 & 1530 & 2098 & 938 & 1522 \\
\hline $\mathrm{Fe}+\mathrm{Zn}$ & 1528 & 2085 & 939 & 1517 & 1376 & 1904 & 819 & 1366 \\
\hline $\mathrm{Fe}+\mathrm{Mn}$ & 1408 & 1974 & 994 & 1459 & 1204 & 1902 & 809 & 1305 \\
\hline $\mathrm{Fe}$ & 1293 & 1974 & 799 & 1355 & 1141 & 1851 & 803 & 1265 \\
\hline $\mathrm{Zn}+\mathrm{Mn}$ & 1148 & 1740 & 609 & 1165 & 805 & 1343 & 411 & 853 \\
\hline $\mathrm{Zn}$ & 1228 & 1616 & 565 & 1136 & 745 & 1199 & 441 & 795 \\
\hline $\mathrm{Mn}$ & 1126 & 1501 & 353 & 994 & 598 & 1082 & 240 & 640 \\
\hline Mean & 1334 & 1868 & 748 & & 1057 & 1625 & 637 & \\
\hline
\end{tabular}

On ardab of grain wheat was $420 \mathrm{LE}$, ton of straw was $660 \mathrm{LE}$ and cost of wheat was $7054 \mathrm{LE} / \mathrm{fad}$., in 2016/2017 seasons (Bulletin of Statistical, 2016).

the highest grain yield and net income $(2.959$, 2.980 ton/fad., and 5422, $5414 \mathrm{LE} / \mathrm{fad}$.) in the $1^{\text {st }}$ and $2^{\text {nd }}$ seasons, respectively.

Total and net income values had markedly varied by foliar application of different micronutrient treatments as shown in same Table. The highest total and net income were detected when spray wheat plants by mixture micronutrients of $(\mathrm{Fe}+\mathrm{Zn}+\mathrm{Mn})$, which were (8644 and $1590 \mathrm{LE} \mathrm{fad}^{-1}$ ) and (8576 and 1522 LE fad. $^{-1)}$, respectively, in the first and second seasons. Whereas the lowest values of total and net income (8048 and 994 and 7694 and 640 LE fad. ${ }^{-1}$ ) were achieved by application of $\mathrm{Mn}$ separately in the first and in the second seasons, respectively. This result may be attributed to increased photosynthetic and growth development due to integrated three micronutrients. Zain et al. (2015) found that foliar application of $\mathrm{FeSO}_{4}+\mathrm{ZnSO}_{4}+\mathrm{MnSO}_{4}$ remained comparatively better regarding yield related attributes of wheat.
Accordingly, the best treatment achieved the highest net income when growing wheat plant following clover as a preceding crop and foliar application by $\mathrm{Fe}+\mathrm{Zn}+\mathrm{Mn}$ mixed, being 2186 and 2098 LE fad. $^{-1}$ in 2016/2017 and 2017/2018 seasons, respectively.

\section{Conclusion}

Under sandy soil conditions, growing fahl clover, following peanut, during the transition period season of succeeding wheat and foliar application of $\mathrm{Fe}+\mathrm{Zn}+\mathrm{Mn}$ mixed at a rate of 500 $\mathrm{mg} \mathrm{L}^{-1}$ in thrice times, increases growth, yield and yield attributes of wheat as well as maximizing total and net income in both seasons. Fe, Mn and $\mathrm{Zn}$ concentration of wheat straw and grain can be increased by foliar Fe, $\mathrm{Mn}$ and $\mathrm{Zn}$ application on potentially $\mathrm{Fe}, \mathrm{Mn}$ and $\mathrm{Zn}$ deficient in sandy soil, and effect occurred in wheat straw and grain when spraying $\mathrm{Fe}$ and $\mathrm{Mn}$ application improved the bioavailability of these micronutrients and increased wheat productivity. 


\section{REFERENCES}

Abdel-Motagally, F.M.F., M.W.Sh. Mahmoud and E.M. Ahmed (2016). Response of two peanuts varieties to foliar spray of some micronutrients and sulphur application under east of El-Ewinat conditions Assiut J. Agric. Sci., (47) 1: 14-30.

Abou-Kerisha, M.A. (1998). Effect of preceding crop and $\mathrm{N}$ fertilizer on the productivity of wheat. J. Agric. Sci. Mansoura Univ., 23 (3): 961-967.

Abou-Kerisha, M.A., R.A. Gadallah and M.M.A. Badr (2008). Effect of preceding and intercropping crops on the productivity of wheat. Minufiya J. Agric. Res., 33 (3): 709728.

Assaf, D., C. Ismail, P. Zvi, O. Levent, M.Y. Atilla, B. Hikmet, S. Yehoshua and F. Tzion (2007). Multiple QTL-effects of wheat gpcbllocus on grain protein and micronutrient concentrations. Physiol. Plant Arum., 129: 635-643.

Aziz, M.Z., M. Yaseen, T. Abbas, M. Naveed, A. Mustafa, Y. Hamid, Q. Saeed, X. Minggang (2019). Foliar application of micronutrients enhances crop stand, yield and the biofortification essential for human health of different wheat cultivars. J. Integrative Agric., 18 (6): 1369-1378.

Badr, S.K.A. (1999). Rotation and preceding crop effects on growth, yield, yield components and grain protein content of wheat (Triticum aestivum, L.) Egypt. J. Appl. Sci., 14 (12): 174-196.

Baldwin, K.R. (2006). Crop Rotations on Organic Farms. North Carolina Cooperative Extension Service. Coll. Agric. and Life Sci., NC State Univ.

Bulletin of Statistical Cost Production and Net Return (2016). Winter Field Crops and Vegetables and Fruit. Agric. Statistics and Econ. Sector, Minist. Egypt. Agric. and Land Reclam., Part (1), Feb. 2016, Egypt.

Chapman, H.D. and P.F. Pratt (1961). Methods of analysis for soils, plants and waters. Division of Agric. Sci., Univ. California, Riverside.
Chaudry, E.H., V. Timmer, A.S. Javed and M.T. Siddique (2007). Wheat response to micronutrients in rainfed areas of Punjab. Soil Environ., 26 (1): 97-101.

Chowdhury, A.K., G. Signh, B.S. Tyagi, P.M. Bhattacharya, A.K. Singh and A. Roy (2008). Assessment of wheat (Triticum aestivum) cultivars to boron deficiencyinduced spike sterility and its impact on grain yield under Terai region of West Bengal. Ind. J. Agri. Sci., 78 (10): 1045-1050.

El-Mehy, A.A., S.K. Badr and Z.M. Attia (2014). Growth, yield and yield components of wheat as affected by crop sequences, seeding rates and nitrogen fertilizer levels. Ann. Agric. Sci., Moshtohor, 54 (1): 1-14.

Gangaiah, B., I.P.S. Ahlawat and B.G. Shivakumar (2012). Crop rotation and residue recycling effects of legumes on wheat as influenced by nitrogen fertilization. Agric. Sci. Res. J., 2 (4): 167-176.

Ghosh, P.K., K.K. Bandypadhyay, R.H. Wanjari, M.C. Manna, A.K. Mishra and M. Mohanty (2007). Legume effect for enhancing productivity and nutrient use efficiency in major cropping systems-an Indian perspective: a review. J Sustain Agric., 30 (1): 61-86.

Grewal, H.S., L. Zhonggu and R.D. Graham (1997). Influence of subsoil zinc on dry matter production, seed yield and distribution of zinc in oil seed rape genotypes differing in zinc efficiency. Pl. Soil, 192 (2): 181- 189.

Gueins, A., M. Alpaslan and A. Unal (2003). Effect of boron fertilization on the yield and some components of bread and durum wheat. Turk . J. Agric., 27: 329- 335.

Jackson, M.L. (1973). Soil Chemical Analysis. Printice Hall, New Delhi, 485.

Khalil, H.E., A.I. Nawar, A.M. AbouElela, A.I.E. Mohammadein and M.E. El-Sodany (2011) Response of maize to $\mathrm{N}$ fertilization following sunflower and winter preceding crops. Alex. J. Agric. Res., 56 (2): 11-19.

Kumar, B. and R.P. Roy Sharma (2000). Effect of preceding crops and nitrogen rates on growth yield and yield attributes of wheat. Indian J. Agric. Res., 34 (1): 34-38. 
Maadi, B., G. Fathi, S. A. Siadat, K. Alami Saeid and S. Jafari (2012). Effects of preceding crops and nitrogen rates on grain yield and yield components of wheat (Triticum aestivum L.). World Appl. Sci. J., 17 (10): 1331-1336.

Maralian, H. (2009). Effect of foliar application of $\mathrm{Zn}$ and $\mathrm{Fe}$ on wheat yield and quality Afr. J. Biotechnol., 8 (24): 6795-6798.

Malakouti, M.J. (2008). The effect of micronutrients in ensuring the efficient use of macronutrients. Turk J. Agric. Forestr, 32: 215-220.

Ouda, K.M.O., A.R. Syed, A. Rafet, F.A. Jawad and N. Abdul-Sattar (2017). Waste-to-energy potential in the Western Province of Saudi Arabia. J. King Saud Univ., 29 (3): 212-220.

Page, A.L., R.H. Miller and D.R. Keeney (1982). Methods of Soil Analysis. Part 2: Chemical and Microbiological Properties. Am. Soc. Agron. Madison, Wisconsin, USA .

Pandey, K.R., S.C. Shah and M. Becker (2008). Management of native soil nitrogen for reducing nitrous oxide emissions and higher rice production. J. Agric. and Environ., 9: 19.

Piper, C.S. (1950). Soil and Plant Analysis. Int. Sci. Publishers, Inc. New York.

Phoomthaisong, J., B. Toomsan, V. Limpinuntana, G. Cadisch and A. Patanothai (2003). Attributes affecting residual benefits of N2-fixing mung bean and groundnut cultivars. Biol. and Fertility of Soils, 39 (1): 16-24.

Reddy, S.R. (2004). Principles of Crop Production - Growth Regulators and Growth Analysis, $2^{\text {nd }}$ Ed. Kalyani Publishers, Ludhiana, India.
Rehm, G. and A. Sims (2006). Micronutrients and production of hard red spring wheat. Minnesota Crop News, Univ. Minnesota. March, $7: 1-3$.

Seif El-Nasr and F.A. Zahran (1998). Yield and yield components of wheat as affected by preceding summer crops and three levels of NPK fertilizer. J. Agric. Sci. Mansour Univ., 23 (12): 5795-5806.

Shah, Z., S.H. Shah, M.B. Peoples, G.D. Schwenke and D.F. Hrridge (2003). Crop residue and fertilizer $\mathrm{N}$ effects on nitrogen fixation and yields of legume-cereal rotations and soil organic fertility. Field Crops Res., 83: 1-11.

Siadat, S.A., M.R. Moradi-Telavat, G. Fathi, M. Mazarei, K. Alamisaeid and S.H. Mousavi (2011). Rapeseed (Brassica napus L. var. oieifera). Responseto Nitrogen Fertilizer Following Different Previous Crops. Italian J. Agron., 6 (31): 199-203.

Snedecor, G.W. and W.G. Cochran (1981). Statistical Methods. $7^{\text {th }}$ Ed. Iowa State Univ., Press, Ame. Iowa, USA.

Waller, R.A. and D.B. Duncan. (1969). Symmetric Multiple Comparison Problem. Ame. Stat. Assoc. Jour. December, 14851503.

Yangx, W., H. Tianxiao, C. Luxin and X. Caoyu (2016). Effect of foliar zinc application on the micronutrients of wheat grain. Agric. Res. Arid Areas, 6: 866.

Zain, M., I. Khan, R.W.K. Qadri, U. Ashraf, S. Hussain, S. Minhas, A. Siddique, M. M. Jahangir and M. Bashir (2015). Foliar application of micronutrients enhances wheat growth, yield and related attributes. Ame. J. Plant Sci., 6: 864-869. 


\title{
تأثير المحصول السابق والعناصر الصغزى على المحصول ومكوناته لقمح الخبز تحت ظروف الأر اضى الرملية
}

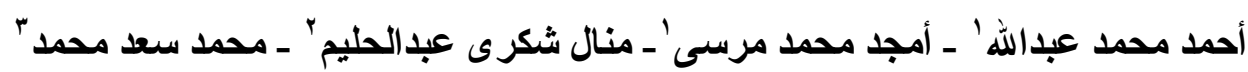 \\ ا ـ معهد بحوث المحاصبل الحقلية_ مركز البحوث الزر اعية ـ مصر

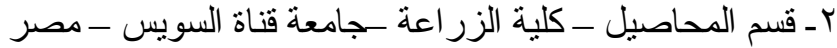

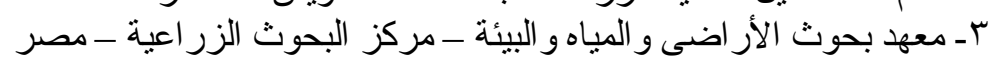

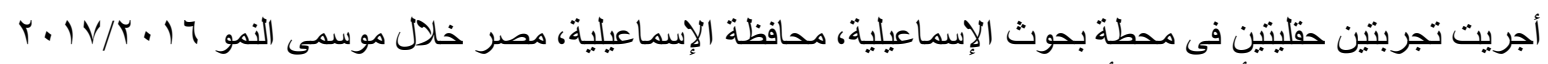

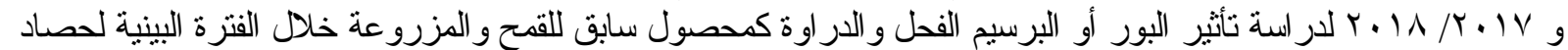

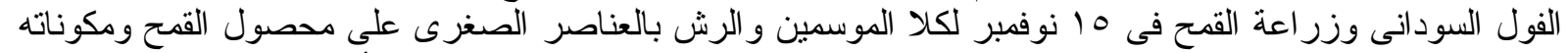

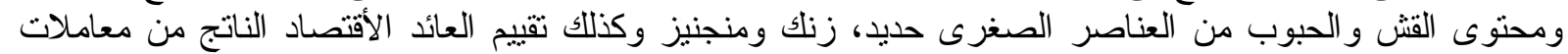

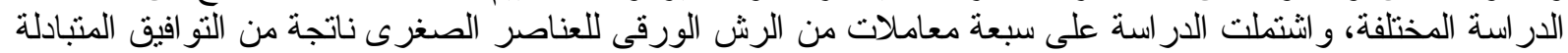
T1: (Fe +Zn + Mn), T2: (Fe +Zn), T3: (Fe + Mn), T4: Fe, T5: (Zn + Mn), T6: Zn and T7: Mn

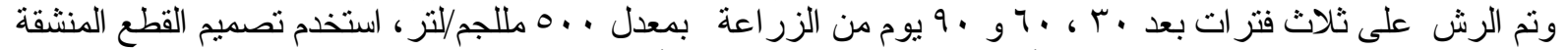

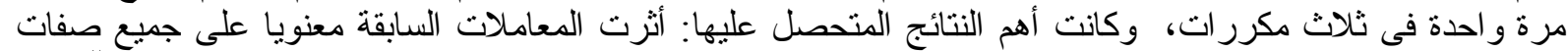

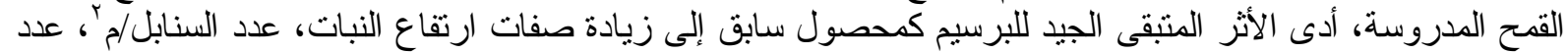

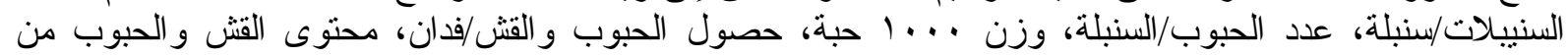

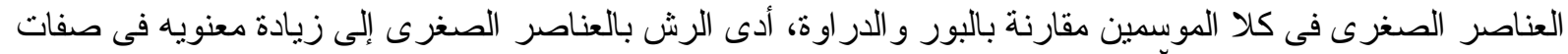

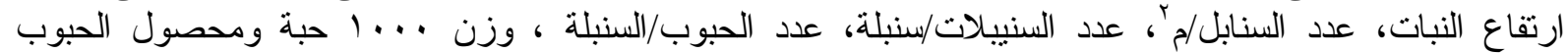

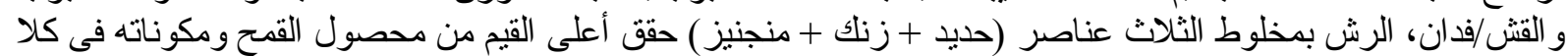

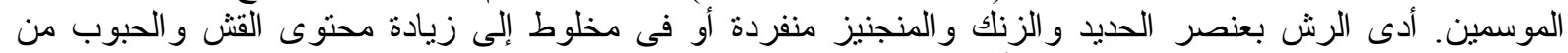

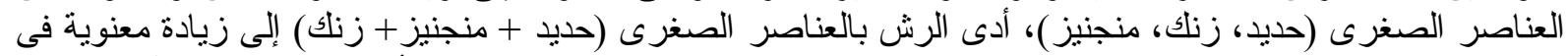

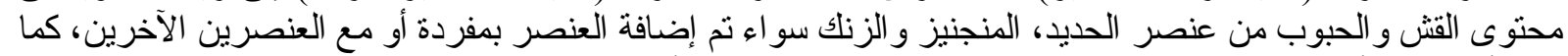

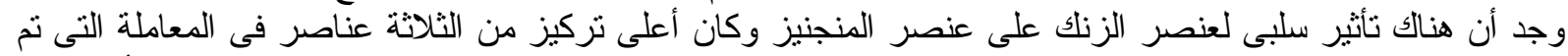

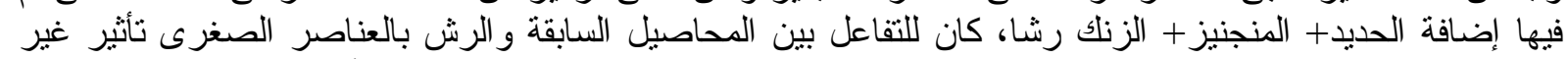

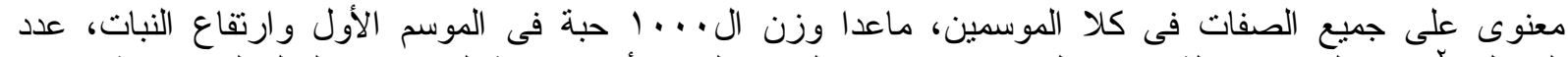

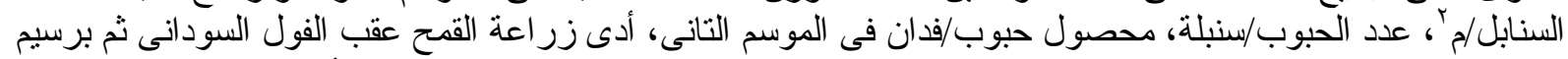

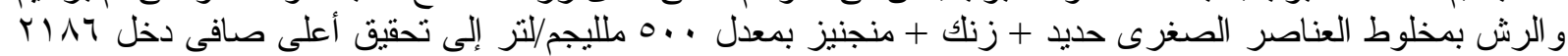

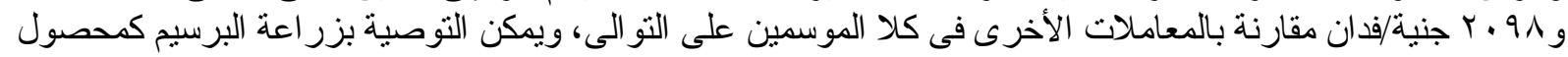

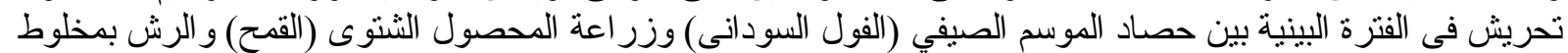

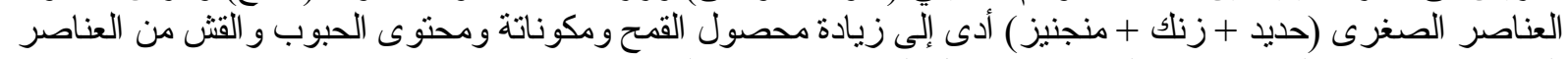

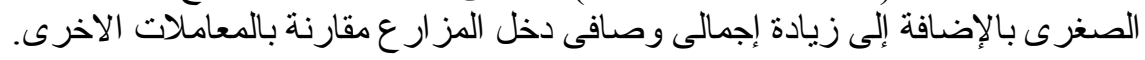

رئيس بحوث المحاصيل المتفرغ - مركز البحوث الزر اعية بالجيزة. 